\title{
EFFECTS OF SPATIAL AND TEMPORAL VARIATION IN SNOW MELT ON NITRATE ION AND SULFATE ION PULSES IN MELT WATERS WITHIN AN ALPINE BASIN
}

\author{
by \\ Mark W. Williams and John M. Melack \\ (Department of Biological Sciences, Marine Science Institute and Computer Systems Laboratory, \\ University of California, Santa Barbara, CA 93106, U.S.A.)
}

\section{ABSTRACT}

Source areas of snow-melt run-off vary spatially and temporally, with corresponding changes in chemistry of the snow-pack, and influence both timing and quality of snow-pack run-off. In the the alpine basin of Emerald Lake, located in the southern Sierra Nevada, California, U.S.A., we have found that nitrate ion $\mathrm{NO}_{3}^{-}$and sulphate ion $\mathrm{SO}_{4}^{2-}$ concentrations in streams were correlated with the amount of snow melt in each sub-basin. Inflows to Emerald Lake had elevated concentrations of $\mathrm{NO}_{3}^{-}, 18 \mu \mathrm{eq} \mathrm{dm}^{-3}$, and $\mathrm{SO}_{4}^{2-}, 9 \mu \mathrm{eq} \mathrm{dm}{ }^{-3}$, which corresponded temporally with the initiation of snow melt in each sub-basin. Concentrations of both anions then decreased as snow melt progressed. The onset of snow melt shifted temporally from sub-basins with a south-westerly aspect to basins with a progressively more northerly aspect. The $\mathrm{NO}_{3}^{-}$and $\mathrm{SO}_{4}^{2-}$ pulses also moved, with time, from the sub-basins with south-westerly aspects to those with more northerly aspects. The time span over which the basin experienced these anionic pulses was longer than that for any single sub-basin. Maximum concentrations of $\mathrm{NO}_{3}^{-}$and $\mathrm{SO}_{4}^{2-}$ in the lake outflow, which also occurred at the onset of snow melt, were elevated by 100 and $40 \%$, respectively, above their January concentrations in line with increases in inflow, but were sustained for a longer period than that of any inflow increase.

\section{INTRODUCTION}

During periods of snow accumulation and melt, physical, chemical, and biological transformations occur within snow-packs. These transformations can alter the concentration and distribution of solutes in the snow-pack, and also lead to the release of the majority of these solutes as an ionic pulse of short duration during the initial phase of snow melt. Snow-pack melt waters with relatively high ionic concentrations are then followed into run-off by relatively dilute ionic solutions. Numerous field and laboratory studies have documented this phenomenon (Johannessen and Henriksen, 1978; Colbeck, 1981; Suzuki, 1982; Cadle and others, 1984; Stein and others, 1986; Rascher and others, 1987).

The understanding of the manner in which snow melt contributes to the chemistry of surface waters in alpine basins is complicated by the rugged and variable terrain, since large topographical differences within short distances result in spatial and temporal variations in the onset of snow melt within a given watershed. Such spatial and temporal differences in snow-melt onset may exaggerate the apparent magnitude and duration of an ionic pulse, or conversely may attentuate the ionic pulse by dilution.

In this study, we examine the way in which variation in the onset of snow-melt run-off affects the magnitude and timing of ionic pulses in sub-basins of an alpine basin. By comparing the solute concentrations of streams draining sub-basins with those of the outflow from the whole basin, we are able to determine whether variation in the onset of snow melt between sub-basins exaggerates or diminshes magnitude and duration of an ionic pulse throughout the entire basin. Our study was conducted in the alpine basin of Emerald Lake (ELB) located in Sequoia National Park, southern Sierra Nevada, California, U.S.A. ELB is representative of alpine catchment zones composed predominately of intrusive igneous rock and subjected to a maritime climate. Stream and lake waters in alpine basins, such as ELB, are amongst the most chemically dilute and weakly buffered in the world (Landers and others, 1987), and are sensitive to any increase in acidic deposition (Melack and others, 1982). Anthropogenic increases in acidity are primarily due to nitric and sulfuric acids, and in this paper we discuss only the anions, $\mathrm{NO}_{3}^{-}$and $\mathrm{SO}_{4}^{2-}$ associated with those strong acids. In this paper, temporal variations of the anions are emphasized.

\section{SITE DESCRIPTION}

The study site is located on the upper Marble Fork of the Kaweah River drainage system in the southern Sierra Nevada of California, U.S.A. $\left(36^{\circ} 35^{\prime} 49^{\prime \prime} \mathrm{N}, 118^{\circ} 40^{\prime} 30^{\prime \prime} \mathrm{W}\right)$. ELB is a north-facing glacial cirque drained by a stream network into Emerald Lake, which itself has a single outflow (Fig. 1). The elevation of the basin is in the range $2780-3416 \mathrm{~m}$ a.s.1., and its topography is steep and rugged in character, with a median slope of $31^{\circ}$. Basin surface area is 120 ha, which is 47 times greater than the surface area of Emerald Lake. More than one-third of the basin is exposed bedrock; most of the remainder of the watershed is rock covered by a thin mantle of talus, colluvium, or poorly developed soil. Only $20 \%$ of the basin is classified as bearing soil. Precipitation is highly seasonal and variable, with about $90 \%$ of the total annual precipitation falling as snow in the period from October through to April. Almost $3000 \mathrm{~mm}$ of precipitation was recorded at Emerald Lake in the water year 30 September-1 October 1986, in contrast with the $1150 \mathrm{~mm}$ which fell in water year 1985 .

\section{METHODS}

Sampling in the Emerald Lake basin spanned the snow-melt seasons of 1985 and 1986. Snow-pit samples for chemical analysis were collected intensively at one site, the inlet, and were also collected periodically at other locations in the basin (Fig. 1). Concurrently with the snow sampling, we sampled the major inflows to Emerald Lake and the Emerald Lake outflow. Sampling sites for water chemistry were located immediately above the lake for all inflows, and immediately below the lake for the outflow.

Integrated samples from the entire snow-pack were obtained by digging pits down to the ground and collecting duplicate, contiguous, vertical cores in increments of $0.4 \mathrm{~m}$. Snow samples were collected using $50 \mathrm{~mm}$ diameter, $0.5 \mathrm{~m}$ long, PVC tubes, which had been washed with $10 \% \mathrm{HCl}$ 


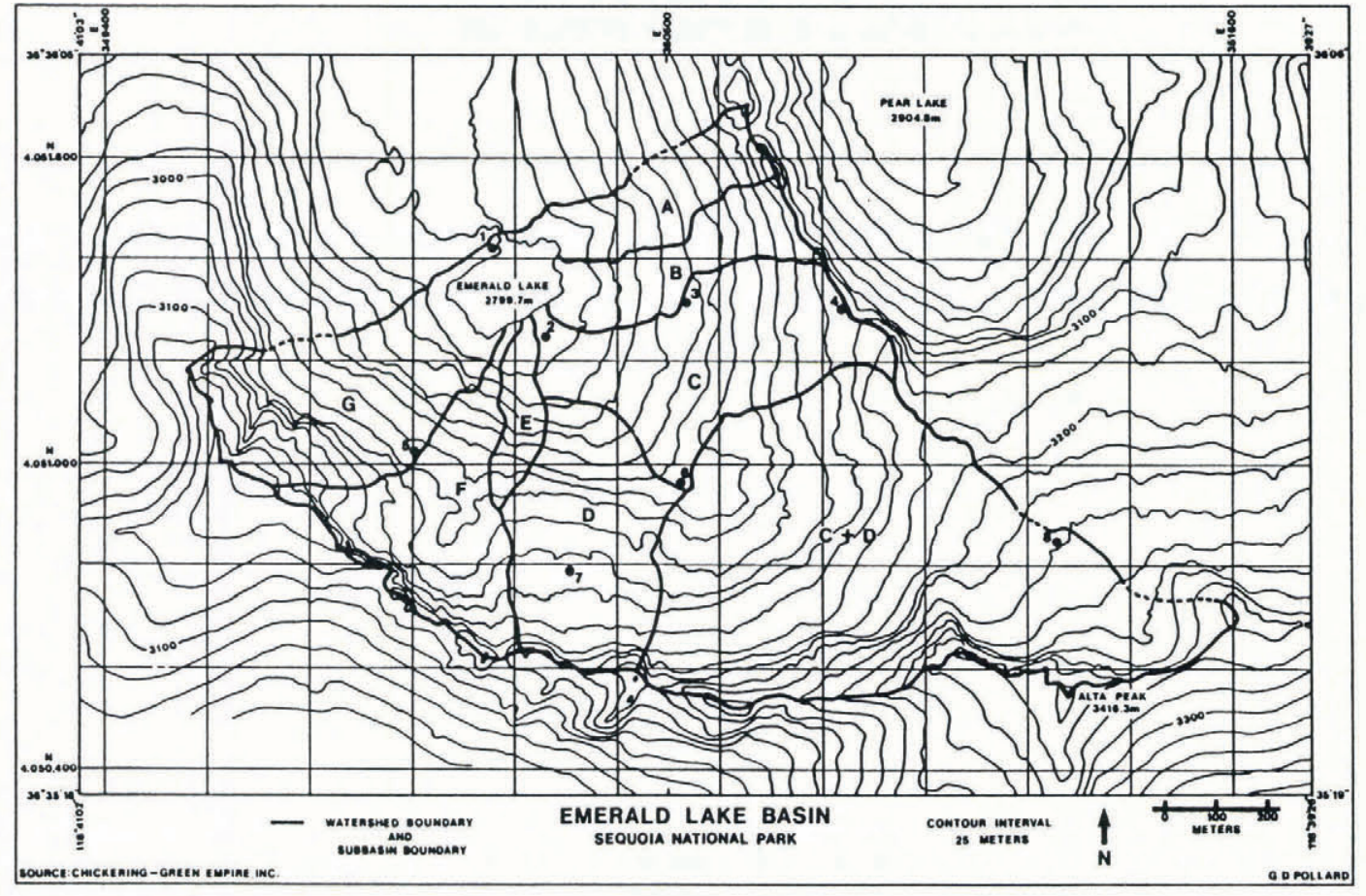

Fig. 1. Topographic map of the Emerald Lake alpine catchment zone. Sub-basins are as follows: $\mathrm{A}=$ east joint, $\mathrm{B}=$ south-east gully, $\mathrm{C}=$ inflow No. $1, \mathrm{C}+\mathrm{D}=$ inflows No. 1 and No. $2, \mathrm{D}=$ inflow No. 2, $E=$ inflow No. $3, F=$ inflow No. $4, G=$ west joint. Sampling sites are as follows: 1 , tower; 2 , inlet; 3 , bench; 4 , ridge; 5 , ramp; 6 , pond; 7 , hole; 8 , cirque.

and carefully rinsed with de-ionized water. The snow cores were decanted into similarly prepared polyethylene bags. Snow samples were stored, frozen, from 3 to 9 months before analysis, and snow-water equivalence (SWE) was determined from the weight of the sample bag and volume of the core. Water samples were collected in acid-washed, linear, polyethylene bottles which had been rinsed with de-ionized water.

Snow samples were placed in covered polyethylene buckets and melted at room temperature. Sub-samples were filtered through pre-rinsed, $47 \mathrm{~mm}$ Gelman A/E glass-fiber filters, and then stored at $4{ }^{\circ} \mathrm{C}$ for subsequent anion analyses. Sample $\mathrm{pH}$ was measured with combined electrodes, such as Sargent Welch S-30072-15 or Ross 8104 suitable for use in dilute solutions and a Fischer Acumet $805 \mathrm{pH}$ meter. Anions were identified and their concentrations measured by ion chromatography with a Dionex instrument, Model $2010 \mathrm{i}$. The standard deviation between replicate samples from snow pits was $\pm 0.1 \mu \mathrm{eq} \mathrm{dm}{ }^{-3}$ for $\mathrm{NO}_{3}^{-}$and $\mathrm{SO}_{4}^{2-}$, and for the water sampled was $\pm 0.2 \mu \mathrm{eq} \mathrm{d^{-3 }}$ for $\mathrm{NO}_{3}^{-}$, and $\pm 0.05 \mu \mathrm{eq}$ $\mathrm{dm}^{-3}$ for $\mathrm{SO}_{4}^{2-}$. Our analytical quality control and quality assurance procedures have been described in Dozier and others (1987).

Snow melt for each sub-basin in 1986 was determined by the random selection of survey points from a $25 \mathrm{~m}$ grid overlain on a contour map with contour lines at $5 \mathrm{~m}$ intervals. Snow depth was then measured with probes in the field at the predetermined survey points. To minimize local variation in snow depth, measurements were taken at the center point and then in the four cardinal-point directions each at a distance of $4 \mathrm{~m}$ from the center point. All five measurements were then averaged to give a single-sample point depth, and then the depths of all sample points within a sub-basin were averaged to obtain a value for snow depth within that sub-basin. Sampling points for each survey varied from 100 to 180 . Snow pits were dug at selected sites in order to make possible the measurement of density. Snow-water equivalence was calculated as the average snow depth in a sub-basin multiplied by the average snow-density value. Four surveys were conducted, with the first starting before the onset of snow melt at maximum snow accumulation.

\section{RESULTS}

The magnitudes of the $\mathrm{NO}_{3}^{-}$and $\mathrm{SO}_{4}^{2-}$ pulses in the snow-pack run-off were determined by finding the differences between the percentage decrease in water content of the snow-pack and the percentage decrease in concentration of each type of ion in the snow-pack (Table I). The ridge site generated a four-fold increase in $\mathrm{NO}_{3}^{-}$ loss, a 2.50 -fold increase in $\mathrm{SO}_{4}^{2-}$ loss, and no enhanced loss for $\mathrm{H}+$ during the period from 14 April 1986 to 23 May 1986. From 5 to 23 May 1986, at the inlet site there was no enhanced $\mathrm{H}+$ loss, but an increase in $\mathrm{NO}_{3}^{-}$and $\mathrm{SO}_{4}^{2-}$ loss in the range 2-2.5 fold was noted. At the inlet and bench sites from 10 to 23 May 1985, the $\mathrm{NO}_{3}^{-}$pulse ranged from 1.7 to 3.7 -fold and $\mathrm{SO}_{4}^{2-}$ was about 1.6 -fold, and $\mathrm{H}+$ about 1.7-fold (Melack and others, in press).

The onset of snow melt shifts temporally from subbasins with a south-westerly aspect to sub-basins with a progressively more northerly aspect (Fig. 2). Snow melt in each of the ELB sub-basins was calculated by subtracting the SWE value from a survey specific from the maximum SWE in that sub-basin, dividing the result by the maximum SWE, and multiplying by 100 . Since no survey was conducted before 16 April 1986, snow-melt values for the south-east gully (SEG; sub-basin B in Figure 1) sub-basin prior to that date were based on the SWE difference between the SEG sub-basin and the adjacent sub-basin (inflow No. 1) on 16 April 1986. Sub-basin C + D is drained by a perennial stream dividing into inflow Nos. 1 and 2 about $200 \mathrm{~m}$ above the lake (Fig. 1). Before discharging into Emerald Lake, these streams are joined by waters from their respective catchment areas. Inflow No. 4 generally freezes during the winter months; in the spring of 1986 it began flowing sometime in early or mid-May. Precipitation and chemical flux from wet deposition to the basin, from the start of snow melt to the last snow survey were negligible, amounting to less than $1 \%$ of the SWE and solutes in the snow-pack at maximum accumulation. Relative ranking of annual discharge from the inflows is No. $2>$ No. $1>$ No. $4>$ SEG > East joint (Fig. 1).

$\mathrm{NO}_{3}^{-}$and $\mathrm{SO}_{4}^{2-}$ concentrations from inflows were correlated with the amount of snow melt in their respective 
TABLE I. SNOW-PIT CONCENTRATIONS, SPRING MELT, EMERALD LAKE BASIN

1985

\begin{tabular}{|c|c|c|c|c|c|}
\hline \multirow[t]{2}{*}{ Date } & Site & SWE & {$\left[\mathrm{H}^{+}\right]$} & {$\left[\mathrm{NO}_{3}^{-}\right]$} & {$\left[\mathrm{SO}_{4}^{2-}\right]$} \\
\hline & & $\mathrm{cm}$ & $\mu \mathrm{eq} \mathrm{dm}^{-3}$ & $\mu e q \mathrm{dm}^{-3}$ & $\mu$ eq $\mathrm{dm}^{-3}$ \\
\hline \multirow[t]{2}{*}{10 May } & Inlet & 23 & 4.6 & 3.3 & 1.7 \\
\hline & Bench & 27 & 4.0 & 3.3 & 1.5 \\
\hline \multirow[t]{7}{*}{23 May } & Inlet & 17 & 2.8 & 1.8 & 1.3 \\
\hline & Bench & 22 & 3.0 & 0.6 & 1.2 \\
\hline & Pond & 32 & 2.3 & 1.1 & 4.0 \\
\hline & Ramp & 47 & 2.8 & 1.4 & 3.0 \\
\hline & Hole & 61 & 3.8 & 1.8 & 1.3 \\
\hline & Cirque & 27 & 2.9 & 0.3 & 3.7 \\
\hline & & & 1986 & & \\
\hline \multirow[t]{2}{*}{14 April } & Ridge & 318 & 3.2 & 1.3 & 1.5 \\
\hline & Pond & 166 & 3.8 & 0.9 & 0.8 \\
\hline \multirow[t]{2}{*}{5 May } & Inlet & 244 & 3.7 & 0.6 & 1.0 \\
\hline & Hole & 232 & 4.3 & 1.3 & 1.2 \\
\hline \multirow[t]{2}{*}{23 May } & Inlet & 198 & 3.6 & 0.5 & 0.7 \\
\hline & Ridge & 264 & 3.7 & 0.5 & 1.0 \\
\hline \multirow[t]{2}{*}{27 June } & Inlet & 191 & 3.2 & 0.3 & 0.1 \\
\hline & Ridge & 141 & 3.4 & 0.2 & 0.2 \\
\hline
\end{tabular}

SWE is snow-water equivalence. Standard deviation for both $\left[\mathrm{NO}_{3}^{-}\right]$and $\left[\mathrm{SO}_{4}^{2-}\right]$ was $\pm 0.1 \mu \mathrm{eq} \mathrm{dm}^{-3}$.

sub-basins. January $\mathrm{NO}_{3}^{-}$and $\mathrm{SO}_{4}^{2-}$ concentrations for inflow No. 2 are similar to those for 14 April, that is about 8 and $6 \mu$ eq dm${ }^{-3}$, respectively. Maximum $\mathrm{NO}_{3}^{-}$and $\mathrm{SO}_{4}^{2-}$ concentrations were measured at the onset of snow melt in inflows Nos. 2 and 4 (Fig. 2). As snow melt progressed, the anionic pulse in stream waters was followed by increasingly diluted ion solutions. The temporal shift in the onset of snow melt was matched by a spatial difference in stream chemistry. On 1 May, $\mathrm{NO}_{3}^{-}$concentrations in the inflows varied from 0 to $17 \mu \mathrm{eq} \mathrm{dm}^{-3}$, with concentrations increasing as the percentage of snow melt decreased (Fig. 2). This trend continued through to 18 May. $\mathrm{SO}_{4}^{2-}$ concentration follow a pattern similar to that for $\mathrm{NO}_{3}^{-}$except that the magnitude of the $\mathrm{SO}_{4}^{2-}$ pulse was smaller, and its duration appeared to be longer.

January concentrations of $\mathrm{NO}_{3}^{-}$and $\mathrm{SO}_{4}^{2-}$ in the outflow water were also similar to those measured on 14 April, at

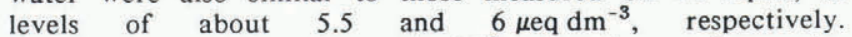
Concentrations of $\mathrm{NO}_{3}^{-}$and $\mathrm{SO}_{4}^{2-}$ in the outflow also increased with the onset of snow melt in the watershed, and then decreased as the snow-melt season progressed. The maximum concentration of $\mathrm{NO}_{3}^{-}$measured in the outflow was $11 \mu \mathrm{eq} \mathrm{dm}^{-3}$, which was about half of the peak value of $18 \mu \mathrm{eq} \mathrm{\textrm {dm } ^ { - 3 }}$ observed in inflows Nos. 2 and 4 . Maximum concentration of $\mathrm{NO}_{3}^{-}$in the outflow occurred between the times at which the maximum values were measured in inflows Nos. 2 and 4 . $\mathrm{NO}_{3}^{-}$concentrations in the outflow remained near their maximum, in the range of 10-11 $\mu$ eq $\mathrm{dm}^{-3}$, for the period of $1-18$ May, but inflow No. 2 showed a rapid decline in $\mathrm{NO}_{3}^{-}$concentration during this period. $\mathrm{SO}_{4}^{2-}$ followed a pattern similar to $\mathrm{NO}_{3}^{-}$.

\section{DISCUSSION}

Ablation results from the complex interplay of physiographic factors such as slope, aspect, latitude, and horizon, with energy-balance exchanges at the air/snow and snow/ ground interfaces (Elder, in press). Thus, source areas of snow-melt run-off vary both spatially and temporally (Woo and Slaymaker, 1975). The onset of snow melt in ELB
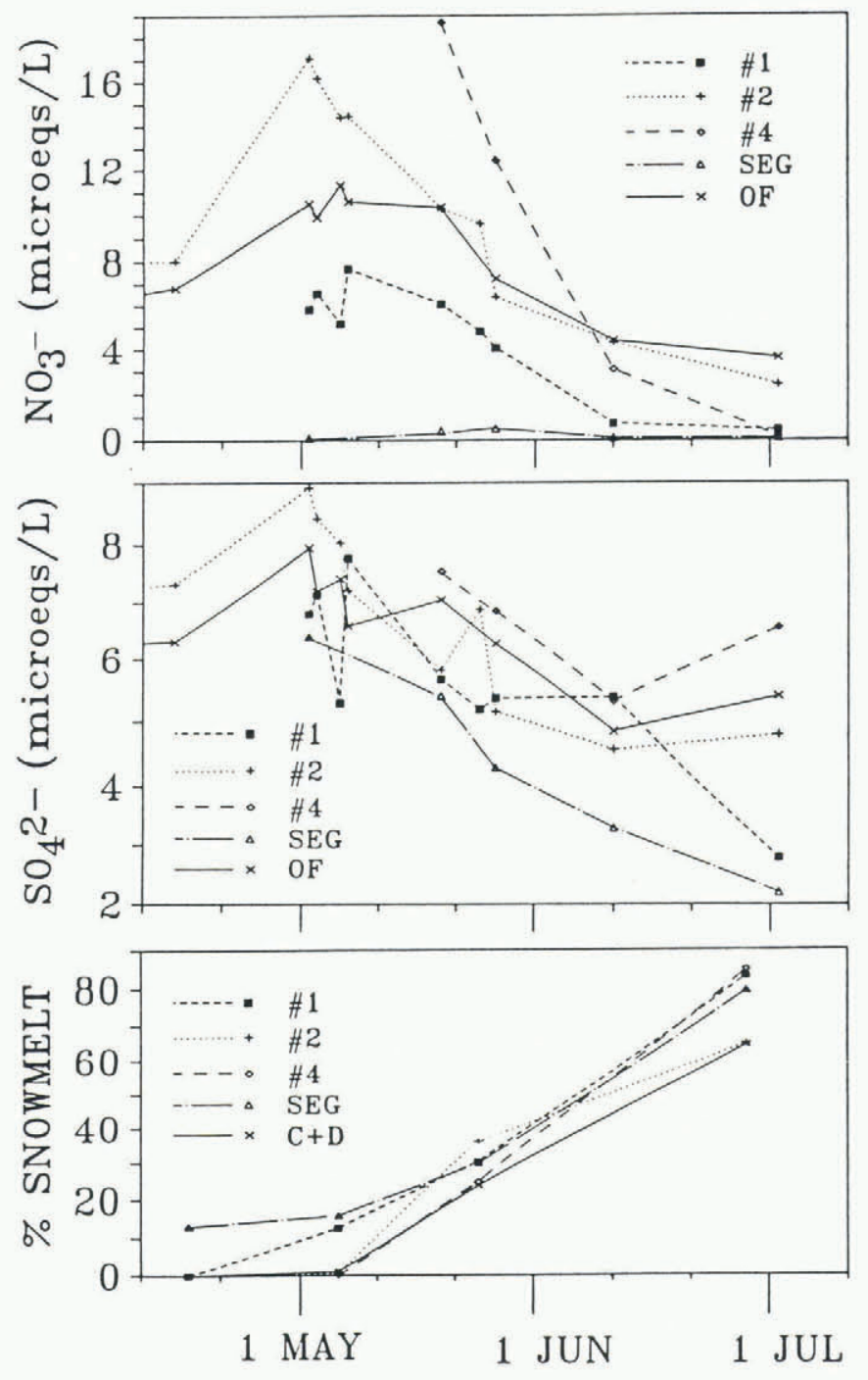

Fig. 2. $\mathrm{NO}_{3}^{-}$and $\mathrm{SO}_{4}^{2-}$ concentrations from streams are compared with those for snow melt from their respective basins. Snow melt on 5 May 1986 was $1 \%$ in the C + D sub-basin and in the inflow No. 2 sub-basin, with no snow melt in the inflow No. 4 basin. Standard deviation was $\pm 0.2 \mu$ eq dm${ }^{-3}$ for $\mathrm{NO}_{3}^{-}$and $\pm 0.05 \mu \mathrm{eq} \mathrm{dm}^{-3}$ for $\mathrm{SO}_{4}^{2-}$. OF, outlet; SEG, south-east gully; No. 1, inflow No. 1; No. 2, inflow No. 2; No. 4, inflow No. 4.

shifts temporally from sub-basins with a south-westerly aspect to those with a progressively more northerly aspect. These ablation differences within a watershed cause a corresponding change in chemistry in both the snow-pack and the snow-pack run-off.

Stream water sampled in ELB sub-basins from January through to July had the highest values of $\mathrm{NO}_{3}^{-}$and $\mathrm{SO}_{4}^{2-}$ at the time of onset of snow melt in each sub-basin. Outflow exhibited a similar anionic pulse with the onset of snow melt in the basin.

In stream water, the $\mathrm{NO}_{3}^{-}$pulse may be due to sources other than an ionic pulse from snow-melt run-off. Ground water, soil water, and organic horizons in the soil may all contribute $\mathrm{NO}_{3}^{-}$to this run-off, although the small percentage of soils and high percentage of bedrock characteristic of ELB make this explanation for the observed ionic pulses unlikely. Furthermore, biological activity of vegetation, soils, and phytoplankton utilizes $\mathrm{NO}_{3}^{-}$as a nutrient source, which would tend to reduce the amplitude of the $\mathrm{NO}_{3}^{-}$pulse in stream waters. Coincident with the $\mathrm{NO}_{3}^{-}$pulse there was also a $\mathrm{SO}_{4}^{2-}$ pulse, and for both the 1985 and the 1986 snow-packs $\mathrm{NO}_{3}^{-}$was eluted in greater concentration than $\mathrm{SO}_{4}^{2-}$. Anionic concentrations in stream waters follow a pattern similar to that for snow-pack elution; maximum concentrations of $\mathrm{NO}_{3}^{-}$in streams at the onset of snow melt were about $100 \%$ greater than the 
corresponding January concentrations, while $\mathrm{SO}_{4}^{2-}$ concentrations at snow-melt onset were about $40 \%$ greater than the matching January concentrations. Finally, measurements of $\mathrm{NO}_{3}^{-}$concentrations in snow-pack melt water in 1987 before contact with the ground showed concentrations five times greater than bulk snow-pack concentrations.

There is an apparent sequential shift in the generation of $\mathrm{NO}_{3}^{-}$and $\mathrm{SO}_{4}^{2-}$ pulses through ELB corresponding with the onset of snow melt in each sub-basin. The period of time during which the whole of the alpine basin experienced these anionic pulses was thus greater than that for any single sub-basin. Lake-water concentrations of $\mathrm{NO}_{3}^{-}$ and $\mathrm{SO}_{4}^{2-}$ may respond to ion pulses by remaining elevated for a longer period of time than those for individual sub-basins, or alternatively may remain unaltered because concentrated ionic solutions in melt water from a sub-basin just starting to undergo melt may be balanced by dilute melt-water ion solutions from a sub-basin in the late stages of snow melt. Ion concentration in water from the lake outflow indicates how the alpine catchment area as a whole was influenced by sub-basin differences in anionic concentration.

Maximum concentrations of $\mathrm{NO}_{3}^{-}$and $\mathrm{SO}_{4}^{2-}$ measured in inflow samples were between 1.5 and 1.1 times those in the sampled outflow. The level of the anionic pulse generated by the inflows was attenuated when these flows were combined in the outflow. What is surprising is that the percentage increases in $\mathrm{NO}_{3}^{-}$and $\mathrm{SO}_{4}^{2-}$ concentrations in the outflow at the onset of spring melt were similar to those in the inflows, namely about $100 \%$ for $\mathrm{NO}_{3}^{-}$and $40 \%$ for $\mathrm{SO}_{4}^{2-}$. Furthermore, outflow concentrations remain elevated to near-maximum values for a much longer period of time than was noted for any of the individual inflows. For the alpine catchment zone as a whole, Figure 2 illustrates how decrease in both $\mathrm{NO}_{3}^{-}$concentration and $\mathrm{SO}_{4}^{2-}$ concentration in inflow No. 2 appears to be balanced by contributions from inflow No. 4, such that $\mathrm{NO}_{3}^{-}$concentration and $\mathrm{SO}_{4}^{2-}$ concentration in the outflow remained elevated for a longer time span than was observed for any individual sub-basin.

\section{CONCLUSION}

Spatial and temporal variations in the onset and intensity of snow melt appear to affect the water chemistry of alpine basins. Concentrations of $\mathrm{NO}_{3}^{-}$and $\mathrm{SO}_{4}^{2-}$ in melt water during spring run-off in alpine basins vary considerably both spatially and temporally, necessitating sampling from all sub-basins adequately to characterize inputs to lake systems in this season. Spatial and temporal variations in onset of snow melt do not appear to reduce the percentage increase in $\mathrm{NO}_{3}^{-}$and $\mathrm{SO}_{4}^{2-}$ pulses in alpine basins; rather these ablation differences appear to increase notably the period over which such areas are subjected to raised concentrations of $\mathrm{NO}_{3}^{-}$and $\mathrm{SO}_{4}^{2}$, and also to extend the period during which these more concentrated solutions are transported into down-stream aquatic systems.

\section{ACKNOWLEDGEMENTS}

K. Tonnessen was helpful in all aspects of our study. D. Clow, R. Kattelmann, and K. Elder shared many a cold snow pit. D. Marks provided direction and enthusiasm as project manager of the snow part of the research. J. Sickman, M. Williams, and H. Hardenburg collected and analyzed water samples; F. Setaro developed our QA and QC protocol for snow-chemistry analysis. We thank S. Hamilton for editorial comments. Funding was provided by California Air Resources contracts A3-103-32 and A3-09632.

\section{REFERENCES}

Cadle, S.H., J.M. Dasch, and N.E. Grossnickle. 1984. Retention and release of chemical species by a northern Michigan snowpack. Water, Air. Soil Pollut., 22, 303-319.

Colbeck, S.C. 1981. A simulation of the enrichment of atmospheric pollutants in snow cover run-off. Water Resour. Res., 17(5), 1383-1388.

Dozier, J., J.M. Melack, D. Marks, K. Elder, R. Kattelmann, and M. Williams. 1987. Snow deposition, melt, runoff and chemistry in a small alpine watershed, Emerald Lake basin. Sequoia National Park. Final report. Sacramento, CA, California Air Resources Board. (Contribution A3-103-32.)

Elder, K., J. Dozier, and J. Michaelsen. 1989. Spatial and temporal variation of net snow accumulation in a small alpine watershed, Emerald Lake basin, Sierra Nevada, California, U.S.A. Ann. Glaciol., 13, 56-63.

Johannessen, M. and A. Henriksen. 1978. Chemistry of snow meltwater: changes in concentration during melting. Water Resour. Res., 14(4), 615-619.

Landers, D.H. and others. 1987. Characteristics of lakes in the western United States. EDA/600/3-86/054a. Washington, D.C.: U.S.EPA.

Melack, J.M., J.L. Stoddard, and D.R. Dawson. 1982. Acid precipitation and buffer capacity of lakes in the Sierra Nevada, California. In Proc. Int. Symp. Hydro-meteorol., 465-471 Amer. Water Resour. Assoc.

Melack, J.M., M.W. Williams, and J.O. Sickman. In press. Episodic acidification during snowmelt in waters of the Sierra Nevada, California. In First International Symposium on Mountain Watersheds. Proceedings.

Rascher, C.M., C.T. Driscoll, and N.E. Peters. 1987. Concentration and flux of solutes from snow and forest floor during snowmelt in the west-central Adirondack region of New York. Biogeochemistry, 3(1-3), 209-224.

Stein, J., H.G. Jones, J. Roberge, and W. Sochanska. 1986. The prediction of both runoff quality and quantity by use of an integrated snowmelt model. International Association of Hydrological Sciences Publication 155 (Symposium at Budapest 1986 - Modelling Snowmeltinduced Processes), 347-358.

Suzuki, K. 1982. Chemical changes of snow cover by melting. Japn. J. Limnol., 43, 102-112.

Woo, M.-k. and O. Slaymaker. 1975. Alpine streamflow response to variable snowpack thickness and extent. Geogr. Ann., 57A(3-4), 201-212. 